\title{
CHALLENGES PRESENTED BY RESEARCH METHODS AND ETHICS IN CULTURAL STUDIES - BLURRED BOUNDARIES BETWEEN PUBLIC AND PRIVATE
}

TOVE INGEBJØRG FJELL

University of Bergen

Faculty of Humanities

Department of Archaeology, History,

Cultural Studies and Religion

Norway, 5020 Bergen, Øysteinsgate 3
DOI: $10.17234 /$ SEC.26.2

Review article

Pregledni rad

Received / Primljeno: 4 August 2014

Accepted / Prihvaćeno: 8 September 2014

This article reflects on the use of internet sources and the associated challenges relating to research methods and ethics. It appears that the premise on which dividing lines are drawn between the private and public spheres, between what lies in the public domain and what is published is not the same in internet discussion forums as in real life. Taking part in an online conversation or posting a contribution to a forum may be perceived as a private or semi-private activity, even if we know that anyone may read the posting: the activity takes place in the public sphere, but is an innately private act and is instinctively felt to be so. Furthermore, the page owners recognise this blurred boundary between private and public spheres, which reinforces the view that text can indeed be published without necessarily becoming part of the public domain. Consequently, research academics and students need to reflect in greater depth on the ways in which they introduce themselves, on whether it is at all possible to obtain consent for the use of internet material, and if so - how. They also need to consider de-identifying internet material in the same way they de-identify data obtained from traditional sources.

Keywords: research ethics, qualitative method, consent, de-identification, the world wide web, internet sources

\section{INTRODUCTION}

Scholars working on culture are faced with a wide variety of material and they therefore encounter a number of different challenges with respect to their research methods and ethics. A new type of source material has appeared in a vast number of cultural studies publications in recent years: data obtained from internet sources. This article will discuss the relationship between traditional types of sources, such as interviews and participant observation, and this new type of source. The main focus will be on the challenges associated with research ethics that internet sources present. 
Qualitative research within the field of cultural studies distinguishes between external and internal sources. External sources are generated without the researcher's involvement (Alver and Selberg 1992:27 ff.). Examples of external sources include local newspapers, information leaflets, government white papers, internet blogs and Facebook pages. Internal sources are generated in an interaction between the researcher and the informant (ibid.). Examples of internal sources include qualitative research interviews and participant observation. External and internal sources can all provide access to the ways in which people form their perceptions of various matters, ranging from heritage and employment to health and ethnicity, to mention but a few. Sources in both categories may provide experiential and empirical material. Successful fieldwork involves being embedded in a certain situation or environment in order to produce apt descriptions that provide a wider contextualisation of that situation or environment. The anthropologist Clifford Geertz refers to this as "thick descriptions", for which some passage of time is required for a broad context to be understood by the researcher regarding a certain phenomenon (Geertz 1993:3 ff.). This means that the scholar may get close to the informant or the archive material. However, the intention is not for the researcher to be close: the premise of good research is being able to switch between an up-close and somewhat detached perspective.

Much source criticism has been conducted within the field of cultural studies, often focusing on interviews, observations and archive material. However, online research has given rise to new challenges, particularly with regard to consent and de-identification. De-identification is a new term increasingly being used the way that anonymisation was previously used by culture scholars. De-identification is a process associated with personal data. We normally distinguish between different types of personal data: 1) identifiable personal data; 2) de-identified data; and 3) anonymous data. Identifiable personal data is linked to, for example, an individual's name or personal identification number. De-identified data is linked via a key to a list of names, and all transcripts and recordings of interviews must be stored in a different location from the list of names. Anonymous data cannot in any way be traced back to particular individuals. 
I intend to discuss the challenges that arise from studying internet material such as discussion forums and Facebook pages ${ }^{1}$. My interest in web material was awakened by my work on a study into childlessness and childfreedom, as I made use of the internet to explore how adoptive parents negotiated adoption. Themed forums gave me access to a great deal of background information about adoption, information which I later used when drawing up theme guides for my interviews, and they provided an effective tool for me to familiarise myself with the field. For example, they gave me an insight into the arguments that were used with respect to whether adoption is a form of immigration and whether an adoptive child can be referred to as an immigrant. There were also discussions about the difference between adopting a child from Ethiopia, which means that the child will look different to his or her Norwegian parents, as opposed to adopting from an Eastern European country, which would give the adoptive parents a greater level of certainty that the child would look like themselves. These discussions would at times lead to long and in many ways painful arguments concerning $\mathrm{A}$ and $\mathrm{B}$ teams among adoptive parents, the $\mathrm{A}$ team being made up of adoptive parents with coloured children and the B team being made up of adoptive parents with white children. But was it strictly necessary to conduct this fieldwork on the internet? Could I not simply have interviewed some adoptive parents? Of course I could have, and I did. Yet the internet provided me with an approach to the topics that were not that easily brought up during an interview.

I will start by explaining the ethical guidelines with which academic researchers and students need to comply. This discussion will be based on existing Norwegian standards, but the general reflections on the various problems can be easily generalised beyond the borders of Norway ${ }^{2}$. By using cases or examples from research experience, including other researchers as well as myself, the dilemma between national ethical

\footnotetext{
${ }^{1}$ I discussed these problems in an earlier article (Fjell 2005).

${ }^{2}$ Researchers may also rely on professional ethical guidelines, such as the ones developed by the American Anthropological Association (http://ethics.aaanet.org/category/statement/), the Association of Internet Researchers (http://ethics.aoir.org), or the American Folklore Society (http://www.afsnet.org/?page $=$ Ethics\&hhSearchTerms $=\% 22$ ethics $\% 22$ ).
} 
standards and individual standards, on the one hand, and on the other, practical solutions in specific studies, will be discussed. The examples traditional sources such as interviews and observations as well as newer sources obtained on the internet - will be used to discuss the following issues: how to gain access, how to inform others of one's presence, and how to obtain informed and free consent. In conclusion, I will be discussing the challenges presented by de-identification.

\section{NATIONAL COMMITTEES FOR RESEARCH ETHICS AND DATA PROTECTION OFFICIALS}

Academic researchers and students who work or study in Norway within the field of cultural studies need to comply with the code of ethics ${ }^{3}$ produced by the National Committees for Research Ethics ${ }^{4}$. In addition to the ordinary code of ethics for research, there are guidelines covering social aspects of online research, dating from $2003^{5}$. However, things change very rapidly in the virtual world and as of 2014 there is a note appended to the latter guidelines: "NOTE! These guidelines are currently considered incomplete and are to some extent obsolete. A revised version has been scheduled for publishing by the end of 2014." $"$

Point 10 of the guidelines provided in the code of ethics is particularly important. It is headed Research licenses and the obligation to report and states that: "All research and student projects that involve the processing of personal data must be reported" ". Personal data is information about an

\footnotetext{
3 https://www.etikkom.no/Forskningsetikk/Etiske-retningslinjer/Samfunnsvitenskap-jusog-humaniora/

${ }^{4}$ https://www.etikkom.no/en/In-English/

5 https://www.etikkom.no/Forskningsetikk/Etiske-retningslinjer/Samfunnsvitenskap-jusog-humaniora/Internett-forsking/

${ }^{6}$ Ibid.

7 https://www.etikkom.no/Documents/Publikasjoner-som-PDF/Guidelines $\% 20$ for $\% 20$ research $\% 20$ ethics $\% 20$ in $\% 20$ the $\% 20$ social $\% 20$ sciences, $\% 201$ aw $\% 20$ and $\% 20$ the $\% 20$ humanities\%20(2006).pdf
} 
individual that can be traced back to a particular informant, either directly or indirectly. Examples of information that can be traced back directly to a specific individual include names and addresses. Information that can be traced back indirectly to a specific individual includes background information which, if brought together, would allow anyone to deduce the identity of the individual. Examples of such background information may be that the informant is a 1) head teacher at 2) an upper secondary school in a 3 ) city in western Norway, and that 4) the school is nationally recognised for its special course for young people with behavioural challenges. This description cannot apply to many schools and if one makes the effort, one will be able to find out who the informant is.

Anyone who is going to collect and analyse personal data, whether by interview or by studying a web page, must have their project registered with a Data Protection Official at the Norwegian Social Science Data Services. ${ }^{8}$ This is done by completing and submitting a special report form provided by the Data Protection Official ${ }^{9}$. The form asks for details about the purpose of the research, whether anything needs to be anonymised or de-identified, how the material will be stored on completion of the project, as well as a draft letter of information for informants, often in addition to the proposed wording for a declaration of consent.

This is the framework within which most research is conducted within the field of cultural studies. Some academic circles and scholars are more aware of this framework than others, but most educators, researchers and students will have to reflect on the issues involved.

\section{HOW TO OBTAIN PERMISSION}

There is no requirement for permission to be obtained in order to conduct a study in the public domain. According to Bente Alver and Ørjar Øyen, scholars normally enjoy liberal freedoms when making observations in the public sphere. People in public spaces - on our streets and squares -

\footnotetext{
${ }^{8}$ http://www.nsd.uib.no/nsd/english/index.html

${ }^{9}$ http://www.nsd.uib.no/personvern/en/notification_duty/meldeskjema?eng
} 
will know that they may be being watched (Alver and Øyen 1997). Anyone who observes human interaction from the vantage point of a street corner or a market square can do so without informing their subjects of study. The rules are entirely different for semi-public spaces, such as institutions like schools, nurseries or hospitals. These places require the researcher to obtain access, normally by asking the management, who are authorised to grant the researcher access to conduct interviews with employees or to observe them for a specified period of time.

Observation and participation can also be undertaken online, in the same way as it is done offline. The web provides a wide variety of rooms and networks. Asynchronous communication can be facilitated through Facebook groups and various discussion groups which are used to talk about everything from grief and parenting problems to relationships, immigration etc. Synchronous communication channels include online computer games and chatting. These are online realities, or virtual realities, which must not be interpreted as new realities but rather as types of reality that incorporate new forms of communication (Sveningsson 2004:49; Gershon 2010). But what sort of permission do we need to conduct online research? Are there any restrictions?

One might think that the internet is a public domain. In a fashion, research on the internet may be viewed as observations of and in the public sphere. But is the internet a public space in the same way as a market square or an airport? After all, it is out there - perhaps available for all to use? Is it not similar to observing events unfold from a street corner? In my experience, this is not the case.

When I set out to study postings submitted to the Forum for Adoption and Forum for Childlessness, I contacted the management of two websites with a very high hit rate, Doktor Online ${ }^{10}$ and Snart Gravid ${ }^{11}$, to ask for permission to post my questions and to make use of contributions to their pages in a study about childlessness and adoption. The owners took a reluctantly positive view, but both voiced concern that their users might feel "monitored" and that my presence might spoil a good atmosphere. How

\footnotetext{
${ }^{10}$ www.doktoronline.no

${ }^{11}$ www.snartgravid.com
} 
would the users react if they found themselves quoted in a publication, one of the page owners wondered ${ }^{12}$.

It appears that page owners adopt various codes of practice that any researcher will need to comply with. When I contacted Doktor Online to ask for permission to use quotes from their forums, they referred to a set of regulations in which postings are defined as copyrighted intellectual property ${ }^{13}$ :

Images and text obtained from Doktor Online cannot be used without the consent of the service providers unless such right has been granted under an agreement with Kopinor, the body protecting copyright holders. Any use of such material which infringes on copyright protected by law or agreement may give rise to liability for damages and is punishable by fine or imprisonment ${ }^{14}$.

Another web page, Barn i Magen ${ }^{15}$, provides services of a similar nature. The page sets out that users are free to use

postings on BarniMagen.com for their private purposes, which includes the reading, downloading to disk and printing of such material. It is an offence to copy or publish any text, image or other material obtained from BarniMagen.com (copyright protected) without the consent of the copyright holders or as in accordance with any statutory rights ${ }^{16}$.

However, being granted the permission of the page owner is one thing, obtaining the consent of individual users is something entirely different. The Kvinneguiden web page sets out the following:

\footnotetext{
${ }^{12}$ Quotes from discussion forums were used without permission in a television documentary about childlessness and sperm donation: the TV channel used verbatim quotes that had been cut and pasted from various childlessness forums. The film displayed the quotes, as well as the contributor's nickname, highlighted across the full screen. This spurred heated debate within the forum. The contributors' main argument was that the text they had posted on the internet could not be used without their permission.

${ }^{13}$ There are some exceptions to this: For example, in the U.S., citations are allowed for scholarly purposes.

${ }^{14}$ www.doktoronline.no

${ }^{15}$ http://www.klikk.no/forum/barnimagen/

${ }^{16}$ www.barnimagen.no
} 
It is an offence to use material obtained from the forum without the prior permission of the owners of Kvinneguiden. Furthermore, it is necessary to obtain the consent of the person who has posted the contribution, as this person holds the copyright to this material under the Norwegian Copyright Act ${ }^{17}$.

If researchers are not at liberty to use quotes without the consent of either the page owner or the contributor, or both, then how should one proceed in order to obtain such consent? And is it in fact possible to obtain free and informed consent?

\section{HOW TO OBTAIN CONSENT}

Researchers are expected to strive to make their presence known to their informants and to obtain their consent, wherever they meet them. One of the guidelines provided in the code of ethics for research stresses the importance of informing the research subjects, i.e. the informants. Point 8 reads:

Research subjects are to be given all the information they require to gain a reasonable understanding of the field of research in question, of the consequences of participating in the research project, and of the purpose of the research.

Furthermore, Point 9 of the guidelines stresses that consent must be given freely:

As a general rule, research projects that include individuals can be initiated only after securing the participants' free and informed consent. The informants have the right to withdraw from participation at any time, without this entailing any negative consequences for them.

The guidelines present their own set of problems: how do we go about informing individuals in a public space, a semi-public space, or a private

\footnotetext{
${ }^{17} \mathrm{http}: / /$ forum.kvinneguiden.no/index.php?app=forums\&module=extras\&section=board rules
} 
space? How do we ensure that the consent we obtain is free and informed? Is this at all possible, whatever the context?

For the sake of argument, we will disregard research undertaken in public spaces, for which consent is not required. But for semi-public spaces there are different expectations, and this is where the code of ethics for research comes into play: if one meets somebody face-to-face, information may be provided by word of mouth or in writing by passing over an informative letter. For my study of birthing practices at hospitals in Norway in the 1990s, the hospital management provided their active consent for me to observe interactions at the clinic; midwives and other staff were never consulted in person and thus granted their passive consent (Fjell 1998; Fjell 2007). Furthermore, the people I interviewed, like doctors, midwives and nurses, gave their active consent in writing, and they signed a consent declaration after having read the transcript of their interview (ibid.).

It is however reasonable to ask how freely the staff at the hospital, a semi-public space, gave their consent. The hospital management had accepted my presence. Did they themselves have a chance to say that they would rather not be studied? Not really. In actual fact, some of the midwives put their foot down and expressed in no uncertain terms that they resented my presence. One of the midwives asked if anybody had asked her for permission. No-one had, so she decided that I could not attend the births for which she was responsible. Of course, this was an awkward situation, but edifying nevertheless with respect to the issues concerning consent.

With respect to online research, things are not that straightforward. My naive starting point when I began making observations on the internet was that the virtual sphere of the world wide web was like a street, a market, a square, to which anyone in principle had access; where whatever was posted was considered communal property. However, as I studied the various contributions to a diverse group of forums, I changed my stance. It became clear to me that the most important question is whether the virtual space is perceived to be a public or private domain by the active contributors on the World Wide Web.

Whether a page is subject to access restrictions or not, researchers should check the website's formal rules and be sure to obtain the page owner's permission to collect data. Page owners point out that 
contributions are protected by copyright, but if we disregard the discussion of whether postings constitute intellectual property for the moment, we can instead approach these issues from a different angle: everyone who contributes actively to social media is familiar with the fact that postings include numerous contributions that concern particular individuals including information about life in general, or about the adversities of life. Contributions to discussion forums, blogs and Facebook groups are produced by so-called "everyday people" who describe their experience of a certain theme in writing. The contributors do not express themselves as if they were broadcasting their views from the middle of a square. They may be talking about heartache, problematic relationships, or deep-felt despair concerning life in general. In one of the many postings about relationship problems ${ }^{18}$, the undersigned "anonymous" purports to have been sickened when she accidentally came across some of the content on her boyfriend's Facebook page:

My boyfriend is a primary school teacher. My job means I spend a lot of time in his class room. Today I happened to go straight onto his Facebook page, because he had borrowed my computer. I was taken straight to a chat between him and a mate and was just about to click off the page when I happened to touch the right-arrow key and the page "scrolled up". I couldn't avoid seeing what was there and started reading.

These messages were written before the two of us started going out. He writes to his mate that "wow, one of those fuckable ladies just logged on... she is SO sexy. She is married with three kids and if that's not bad enough, her daughter is in my class ;-) But no-one will know....The mate answers "get it on :P"

I feel sick. I work in the presence of this girl almost every day, have seen her mother a few times and have heard a bit about her, conversations they have had about the daughter, the class etc. Even if this was before my time it makes me queasy. He has had a

${ }^{18}$ Doktor Online's relationship page. 
relationship with the mother of a girl in his class. She is married!!! And he's joking about it.

What if they are still at it? It's not long ago that she attended one of his one-to-one parent meetings.

What should I do? I would like to confront him, hear him say he's sorry, hear him promise that there's nothing there, but then I've been snooping around on his Facebook, so am I strictly speaking entitled to know anything at all about this, after all it was (hopefully) before we started dating.

I just think it's completely insane. What would you have done? ${ }^{19}$

The contributor receives a number of responses. Some recommend that she talk to her boyfriend about it while others ask her to forget the whole thing. On the same page, under the heading "Parents - children", an anonymous contributor asks for advice about her teenage daughter:

I have a thirteen-year-old girl who normally goes to bed without any fuss between 21.30 and 22.00; she soon falls asleep and wakes up rested and cheerful the next morning. Everything is fine, as long as it's a normal weekday and both adults are at home.

Occasionally we are both out in the evening (training, visiting friends, work) - it's very rare that we are both out, but it does happen. We used to have a babysitter until about a year ago, when our oldest, who is now fifteen, started feeling awkward about having older girls "looking after" them. If we're out in the evening, we get back home around ten or eleven; we are never more than five to twenty-five minutes away, and we are available on the phone.

What happens is that our daughter finds it impossible to relax and fall asleep if the kids are on their own, even if one of their grandparents is

${ }^{19}$ Doktor Online. The Relationships page. Anonymous contributor. 
in the house. She doesn't like us being out in the evenings at all. This autumn things were ok a couple of times, but not so after Christmas. It doesn't happen often, twice a month tops. Also, she isn't happy about me going out in the evening (with her dad staying at home); she is unable to settle unless I say goodnight.... She despairs if she doesn't fall asleep when she should and lies awake thinking about us and about not getting enough sleep.

It's really quite awkward! I didn't think teenagers were so dependent on their parents' goodnight kiss. She's fine when she sleeps elsewhere (she's never homesick if she's at a sleepover or away on a trip, even if I'm not with her), it's the normal everyday falling-asleep routine she needs to stick to every night. I have tried to talk to her, and she is clearly of the opinion that I shouldn't be doing anything at all away from home in the evenings ;-)

Can anybody give advice as to how to resolve this so she'll feel just as safe when I'm not at home? She is not frightened of anything specific, and she does have her siblings in the house (and sometimes granny or granddad, and her dad of course, unless he's with me), so I cannot understand her. ${ }^{20}$

Researchers often feel like intruders, and with material like this, that particular sensation comes easy. The contributors write as if they are talking to their counselor or doctor, or are sitting round the coffee table with friends. But of course, that is far from the case, as they are in fact in the most public of domains, i.e. on the internet. The anthropologist Patricia G. Lange (2008) discusses social networking on YouTube and argues that there is a nuanced sense of publicness and that communication technologies may alter notions of public and private. Furthermore, in a study on UK bloggers, the anthropologist Adam Reed (2005) argues that bloggers see themselves as the main reader of the blog, and that the blogs originally are set up as online diaries, a way of remembering certain moments in one's life ${ }^{21}$. The

\footnotetext{
${ }^{20}$ Doktor online. The parent - child page. Anonymous contributor.

${ }^{21}$ For further reading on communication and new technology, and new notions of public and private, see anthropologist Ilana Gershon's study on the use of Facebook (2010).
} 
question we need to ask ourselves as researchers, if we want to make use of this type of material, is whether a statement was intended to be made in the public domain, or whether it may have been published despite the fact that the intention was for it to remain private. What intentions can we envisage that the contributor may have had?

We must assume that contributors, mentioned in the examples above, write about their frustrations on being a girlfriend or a parent on a web page primarily to seek the help of others, in the form of advice or comfort: their expectation will not be for their written contribution to be used in a research context, not without the researcher asking for their permission at any rate. How, then, can researchers advertise their presence and ask for consent to make use of such material? According to the ethical guidelines for online research it is generally acceptable to use material obtained from open forums without obtaining the consent of those who have provided the information, but out of respect for participants the researcher should inform them of any systematic registration ${ }^{22}$. Forums that are subject to access restrictions provide a different research situation. This was topicalised in a study about the sense of identity in Kvens, an ethnic minority in northern Scandinavia, undertaken by the culture scholar Anette Basso (Basso 2012). Some of Basso's material was obtained from a Facebook page with restricted access ${ }^{23}$. After having contacted the group administrator and having obtained permission to study the group, she introduced herself on the group's page. She did this by posting her own Facebook profile with her picture and full name and by linking this to a blog that she had set up specifically for the study. The blog allowed anyone to read about Basso's study in greater detail should they want to (Basso 2012: 24-25).

The risk associated with announcing one's presence is that the communication within the group, and its focus, will shift, as experienced by the American researcher Barbara Sharf (Sharf 1999). Sharf was undertaking a study of a discussion forum for women who had been diagnosed with breast cancer, and in all her contributions to this forum she pasted in a brief presentation of herself: who she was, what her research was and how

\footnotetext{
${ }^{22}$ Point 4: The difficulties of distinguishing between public and private information.

${ }^{23} \mathrm{https}$ ://www.facebook.com/groups/kvenerutavskapet/?fref=ts
} 
she could be contacted. Because she wanted to make use of some of this communication in her research, she contacted everyone who had given their email address in their contributions and asked each of these individuals to give their consent by email. It is important to point out that none of Sharf's informants considered their contributions to be in the public domain, and none of them felt she could use them without their consent. The informants felt that if she were to cite them without their consent she would be exploiting people who found themselves in a difficult situation; she would be a harvester of words who profited from other people's misfortune.

Barbara Sharf did get the required approval. But in other studies it may well be difficult, even impossible to obtain consent. Some times it may be difficult to get hold of the person whose consent one needs, while on other occasions the cited person may choose not to respond to the enquiry. The culture scholar Kjersti Juely Sandvold Nising undertook a study of the online immigration debate in the aftermath of the massacre of 22 July 2011, when 77 people were killed at Utøya island and in the government quarters of Oslo. She studied a Christian forum, a nationalist forum and an ordinary newspaper comment column (Nising 2013). She had been given permission to study the discussions by the page owners of two of the forums, while the third had failed to respond to her enquiry. Nising considered that the page owner of this forum would have had the opportunity to refuse her study of the discussions, yet failed to do so. Her study involved 203 contributors to the discussions. Obtaining the consent of every individual would have been impossible because they never provided any contact details and because the discussions were closed by the time Nising conducted her study (Nising 2013:19).

\section{HOW TO DE-IDENTIFY}

Researchers within the field of cultural studies are used to anonymisation, or de-identification which is the current terminology. Sometimes, de-identification may be neither possible nor desirable, examples of which include the folklorist Ulf Palmenfelt's writing about the Gotland collector of legends Per Arvid Säve (Palmenfelt 1994), and the folklorist Bente Gullveig Alver's writings about the celebrity clairvoyant 
Anna Elisabeth Westerlund (Alver 2009). Neither was it possible nor desirable for the students who wrote about Norwegian Antarctic explorers (Murvold 1998) to de-identify their informants, nor for the students who wrote about Bergen as a European City of Culture in the year 2000, interviewing the city's local councillors (Hernes 2003).

On other occasions, the informants themselves wish to have their real name in print, because they feel they want to "stand by what they said". The informants may well be able to stand by their own statements, but the question that researchers need to ask themselves is whether the informant is in full control of the research situation. For example, informants normally have no knowledge of how the researcher will select statements from, say, a thirty-page interview, or what context they will appear in. Only the researcher is in control of these aspects, and should therefore not leave the decision to the informant. In other studies, we often find that the informant Peter is consistently referred to as "Anton" while the informant Lisa is consistently referred to as "Julie", and that places of residence are given new names. The need for confidentiality is covered by Point 14 of the guidelines provided in the code of ethics for research:

Research subjects are entitled to a guarantee that all information they provide about their private lives will be treated confidentially. Researchers must prevent the use and dissemination of information that could harm individual research subjects. Research material must usually be anonymised ${ }^{24}$, and strict requirements must apply for how lists of names or other information that would make it possible to identify individuals are stored and destroyed.

A simple de-identification process ensures that informants are given different names, and that any "third person", i.e. an individual to whom reference is made in the interviews, is also given a different name; place names are changed as well. De-identification can also be achieved by removing dialectal expressions, and by using general age categories rather than a specific age, for instance by saying that the informant is in his forties rather than giving his age as forty-seven at the time of the interview. Further de-identification can be achieved by avoiding links between quotes and a

${ }^{24}$ In this quote, «anonymise» and «de-identify» are used as synonymous terms. 
specific name, to make sure it is impossible to follow the informant "Anton" throughout a master's thesis, thereby forming a biographical profile of him through his accounts. Occasionally, further de-identification is ensured by holding back any information provided about the nature of an informant's work and social background. Additionally, the stories featured in the informants' accounts can be paraphrased, or the link between the account and any particular person may be removed. This is done whenever it is imperative that the risk of recognising the informants is minimised. Two examples involve a study of young girls who carry out violence against girls (Natland 2009), and of men who suffer abuse at the hands of their female partners (Fjell 2013). These two studies may be criticised for failing to generate the desired thick descriptions (cf. Geertz 1993), in that the empirical data provided is consciously made "thin".

In some cases radical de-identification is required: one example is a study of hospitalised burns patients undertaken by the anthropologist Anne Kvalheim (Kvalheim 1995). The burns unit featured in her study was very small, with only eight patients in residence during large parts of Kvalheim's field work period. A simple de-identification process, such as a change of names, would still render the informants recognisable to a number of people, like fellow patients, their relatives and staff at the unit. Kvalheim therefore elected to present a prototype burns patient, compiled by the researcher herself ${ }^{25}$.

Online research presents us with a set of new challenges. Point 8 of the ethical guidelines for online research insists that the researcher take due consideration of the fact that it may be possible to trace an informant's identity by undertaking a full-text search of quotes. In my view, it is therefore important to proceed with the utmost care in connection with any research whenever it is felt necessary to use direct quotes from chat groups and postings on bulletin boards. I will now explain why.

\footnotetext{
${ }^{25}$ Prototype informants have been compiled in other contexts, albeit for different purposes than de-identification. In a study by ethnologist Ylva Hagström she presents "Elin", a female profile compiled on the basis of interviews with three different women (Hagström 2000). Hagström chose this method, not as part of a radical de-identification process, but to demonstrate the qualities that link the informants.
} 
Some researchers argue that nicknames can be used without restriction, because they are not the real names of anyone. However, a number of search engines enable searches for nicknames and will list every contribution posted under this nickname. If we read all such online contributions, it may sometimes be possible to put together snippets of information and eventually learn a considerable amount of detail about the person behind the nickname, occasionally even his or her identity.

Using direct quotes from internet forums is clearly not unproblematic. In the same way that one can search for a nickname, one can search for parts of a specific posting, thereby finding out where the contribution was written and what nickname posted it. Sometimes - if one is particularly interested in going out of one's way to do so - it is possible to form a profile of a fictitious or real person. In such cases it will be difficult to protect the integrity of the individual concerned. Nising encountered this problem in her study of immigration debates in three discussion forums (2013). Her solution to the challenge was to gently re-phrase the quotes she used, to ensure that noone would be able to search for and find the exact citations. This is how she explains her procedure:

The changes are only minor, like using synonyms for certain words or re-wording some of the phrases; the meaning of each sentence remains the same. I have searched for all of the re-phrased quotes to ensure that the users will retain their anonymity (Nising 2013: 18).

She took account of the fact that she had no opportunity to reach the contributors to obtain their consent, and that some contributors were using their full name, for example in newspaper debates, which formed part of her material. Anette Basso opted for a different approach in her study of Norwegian-born Kvens and their sense of identity. The quotes from the Facebook group titled "Kvener ut av skapet" (Kvens out of the closet) are not credited to any names, but she has obtained the consent of every individual and she cites them verbatim: "In this way, individuals are neither identified nor invalidated through the process of de-identification" (Basso 2012:27). 


\section{CONCLUSION}

It appears that in online discussion forums the dividing lines between the private and public sphere, between being published and being accessible in the public domain, are drawn in different ways than offline. Participating in a chat or posting a contribution to a forum can be perceived as a private or semi-private act, even if it is evident that anybody may read the posting. The activity takes place in the public sphere but is nevertheless an innately private act, and is perceived as such by the contributors (cf. Lawson 2004; Sharf 1999). Furthermore, the page owners recognise this blurred boundary between the private and the public spheres, thereby re-enforcing the view that some things may have been published without necessarily appearing in the public domain. In consequence, academic researchers and students must give careful thought to the way in which they introduce their presence, whether it is possible to obtain consent for the use of online material, and if so - how. They must also reflect on the need to de-identify their internet material in the same way that they de-identify data obtained from traditional sources.

\section{REFERENCES}

ALVER, Bente Gullveig and Torunn SELBERG. 1992. Det er mer mellom himmel and jord. Folks forståelse av virkeligheten ut fra forestillinger om sykdom and behandling. PhD thesis. Oslo: Vett \& Viten.

ALVER, Bente Gullveig and Ørjar ØYEN. 1997. Forskningsetikk i forskerhverdag. Vurderinger and praksis. Oslo: Tano Aschehoug.

ALVER, Bente Gullveig. 2009. Anna Elisabeth Westerlund-en fortelling. Oslo: Spartacus.

BASSO, Anette. 2012. A gjøre kvensk. Identifikasjon, deltakelse and valg av strategi. Postgraduate thesis. Bergen: University of Bergen.

FJELL, Tove Ingebjørg. 1998. Fødselens gjenfødelse. Fra teknologi til natur på fødearenaen. Kristiansand: Høyskoleforlaget.

FJELL, Tove Ingebjørg. 2005. "Offentliggjort, men inte offentligt? Några tankar om bruket av Internetkällor". In Frågelistan som källa och metod, ed. Charlotte Hagström and Lena Marander-Eklund. Lund: Studentlitteratur, 177-189.

FJELL, Tove Ingebjørg. 2007. "Research in the Minefield of Privacy and Intimacy: The Problems of Consent." In Research Ethics in Studies of Culture and Social Life, ed. Bente Gullveig Alver, Tove Ingebjørg Fjell and Ørjar Øyen. Helsinki: Academica Scientiarum Fennica, 96-113. 
FJELL, Tove Ingebjørg. 2013. Den usynliggjorte volden. Om partnervold mot menn. Trondheim: Akademika.

GEERTZ, Clifford. 1993. The Interpretation of Cultures. London: Fontana Press.

GERSHON, Ilana. 2010. The Breakup 2.0. Disconnecting over New Media. New York: Cornell University Press.

HAGSTRÖM, Ylva. 2000. "Elin - om kroppar, rum och det svårgripbara". In Portätt utan ram. Kön och sexualitet bortom strukturalismen, ed. Ylva Hagström, Lena Martinsson, Magnus Mörck and Magdalena Petersson. Lund: Studentlitteratur, 205-223.

HERNES, May Britt Nesje. 2003. Kultur som redskap. En studie av Bergen som europeisk kulturby 2000. Postgraduate thesis. Bergen: University of Bergen.

KVALHEIM, Anne. 1995. Antropologi and smerte. Smertens antropologi and den antropologiske smerte. Noen refleksjoner. Postgraduate thesis. Bergen: University of Bergen.

LANGE, Patricia G. 2008. "Publicly Private and Privately Public: Social Networking on YouTube." Journal of Computer-Mediated Communication 13: 361-380. DOI: 10.1111/j.1083-6101.2007.00400.x

LAWSON, Danielle. 2004. "Blurring the boundaries. Ethical considerations for online research using synchronous CMC forums". In Readings in Virtual Research Ethics. Issues and Controversies, ed. Elizabeth A. Buchanan. Hershey: Information Science Publishing.

MURVOLD, Hilde Karin. 1998. I helters spor. Sydpolekspedisjonens kulturelle konstruksjon. Postgraduate thesis. Bergen: University of Bergen.

NATLAND, Sidsel. 2009. Volden, horen and vennskapet: Fortellinger om unge jenters voldsbruk. En kulturanalyse. Trondheim: Tapir akademiske forlag.

NISING, Kjersti Juely Sandvold. 2013. Innvandringsdebatt på internett. En analyse av holdninger and diskurser $i$ nettfora. Postgraduate thesis. Bergen: University of Bergen.

PALMENFELT, Ulf. 1994. Per Arvid Säves möten med människor och sägner. Folkloristiska aspekter på et gotländsk arkivmaterial. PhD thesis. Stockholm: Carlsson.

REED, Adam. 2005. “'My blog is me': Texts and persons in UK online journal culture (and anthropology". Ethnos: Journal of Anthropology 70:2, 220-242. DOI: $10.1080 / 00141840500141311$

SHARF, Barbara. 1999. "Beyond netiquette. The ethics of doing Naturalistic Discourse Research on the Internet." In Doing Internet Research. Critical Issues and Methods for Examining the Net, ed. Steve Jones. London: Sage, 243-256.

SVENINGSSON, Malin. 2004. "Ethics in Internet ethnography." In Readings in Virtual Research Ethics. Issues and Controversies, ed. Elizabeth A. Buchanan. Hershey: Information Science Publishing. 


\section{INTERNET REFERENCES}

American Anthropological Association. Statement on ethics. http://ethics.aaanet.org/ category/statement/ (accessed September 14, 2014)

American Folklore Society. Statement on ethics. http://www.afsnet.org/?page=Ethics\&hh SearchTerms $=\% 22$ ethics $\% 22$ (accessed September 14, 2014).

Association of Internet Researchers. Ethics guide. http://ethics.aoir.org/index. php?title=Main_Page (accessed September 14, 2014).

Barn i Magen. www.klikk.no/forum/barnimagen/ (accessed June 16, 2014).

Data Protection Official for Research. http://www.nsd.uib.no/personvern/en/notification duty/meldeskjema?eng (accessed May 31, 2014).

Doktor Online. www.klikk.no/helse/doktoronline/ (accessed June 16, 2014).

Forskningsetiske retningslinjer for forskning på internett. https://www.etikkom.no/ Forskningsetikk/Etiske-retningslinjer/Samfunnsvitenskap-jus-og-humaniora/ Internett-forsking/ (accessed June 3, 2014).

Guidelines for Research Ethics in the Social Sciences, Law, and the Humanities.

https://www.etikkom.no/Documents/Publikasjoner-som-PDF/Guidelines $\% 20$ for $\% 20$ research $\% 20$ ethics $\% 20 \mathrm{in} \% 20$ the $\% 20$ social $\% 20$ sciences, $\% 201$ aw $\% 20$ and $\% 20$ the\%20humanities\%20(2006).pdf (accessed May 30, 2014).

"Kvener ut av skapet" - Facebook group. https://www.facebook.com/groups/ kvenerutavskapet/?fref=ts (accessed June 6, 2014).

Kvinneguiden. http://forum.kvinneguiden.no/index.php?app=forums\&module=extras\&s ection=boardrules (accessed June 14, 2014).

The National Committee for Research Ethics in the Social Sciences and the Humanities (NESH). https://www.etikkom.no/en/In-English/Committee-for-Research-Ethicsin-the-Social-Sciences-and-the-Humanities/ (accessed May 30, 2014).

The Norwegian National Committees for Research Ethics. https://www.etikkom.no/en/ In-English/ (accessed May 30, 2014).

Norwegian Social Science Data Services. http://www.nsd.uib.no/nsd/english/index.html (accessed May 31, 2014).

Snart Gravid. www.snartgravid.com/ (accessed June 16, 2014). 
Tove Ingebjørg Fjell

Izazovi postavljeni istraživačkim metodama i etikom u kulturalnim studijima zamagljene granice između javnog i privatnog

U članku se razmatraju upotreba internetskih izvora i s njome povezani izazovi u istraživačkim metodama i etici. Čini se da polazišta za iscrtavanje razdjelnica između privatne i javne sfere, između onoga što ostaje u javnoj domeni i onoga što se objavljuje, nije isto na internetskim forumima i u stvarnom životu. Sudjelovanje u online razgovorima ili postavljanje komentara na forum može se shvatiti kao privatna ili poluprivatna aktivnost, čak i ako znamo da svatko može pročitati naše objave: aktivnost se odvija u javnoj sferi, ali je suštinski privatni čin i tako se instinktivno i doživljava. Nadalje, vlasnici stranica prepoznaju ovu zamagljenu granicu između privatne i javne sfere, što osnažuje stajalište da tekst zbilja može biti objavljen, a da ne postane nužno dijelom javne domene. Posljedično, istraživači i studenti trebaju podrobnije razmisliti o tome kako se predstavljaju, o tome je li uopće moguće dobiti dozvolu za upotrebu internetskog materijala i ako jest - kako. Također trebaju uzeti u obzir deidentifikaciju internetskog materijala na isti način na koji deidentificiraju podatke prikupljene iz tradicionalnih izvora.

Ključne riječi: istraživačka etika, kvalitativna metoda, pristanak, deidentifikacija, world wide web, internetski izvori 